\title{
EVALUAREA INDICILOR CITOGENETICI LA CELULELE CALUSALE OBȚINUTE DIN EMBRIONI MATURI DE TRITICALE SUB ACȚIUNEA RADIAŢIEI GAMA
}

\author{
Ciobanu Renata \\ Institutul de Genetică, Fiziologie şi Protecţie a Plantelor, Chişinău, Republica Moldova \\ e-mail: renataciobanu3@gmail.com
}

Radiaţiile ionizante s-au dovedit unul din mijloacele eficiente de intervenţie în schimbarea structurii genetice a speciilor, în crearea şi ameliorarea soiurilor, fiind o sursă preţioasă de sporire a variabilităţii genetice. Efectele acţiunii radiaţiei gama asupra triticalelor sunt multiple şi depind de o serie întreagă de factori: doza, durata de iradiere, genotip. Mutaţiile apărute în cultura in vitro pot avea origine diferită şi cuprinde un spectru variat de restructurări cromozomiale, similare celor induse de alţi factori fizici şi chimici. În rezultatul iradierii ţesuturilor vegetale apar multiple rupturi şi modificări ale structurii fine a cromozomilor, fiind caracterizate prin instabilitatea genomului celulelor.

Embrionii maturi de triticale au fost prelevaţi de la genotipurile: Ingen 33, Ingen 35, Ingen 40, Ingen 93, Polonez LT 76872, Rodlen, Colina, 188TR5021, CAD 2/917 şi supuşi iradierii gama cu doza de 150 Gy la instalaţia gama RXM-V-20, sursa radiaţiilor $-{ }^{60} \mathrm{Co}, 0,16 \mathrm{~g} / \mathrm{sec}$. Pentru inducerea calusogenezei embrionii au fost inoculaţi pe mediul Murashige şi Skoog (1962) suplimentat cu mezoinositol $(250$ mg/l), 2,4-D (2 mg/l), kinetină $(0,2$ mg/l), zaharoză $(30$ g/l), agar $(7$ g/l), pH-ul 5,8. La etapa de inducere, explantele au fost cultivate la întuneric în camera de cultură la temperatura $26 \pm 2^{\circ} \mathrm{C}$, timp de 4 săptămâni. Calusul obţinut a fost fixat în soluţie de alcool-acid acetic glacial (3:1), probele de calus au fost tratate cu soluţie de alaun (7\%), supuse hidrolizei şi macerării preventive cu pectinază $(0,5 \%)$ şi colorarea celulelor calusale în soluţie carmin-acetic ( $2 \%)$ timp de 24 de ore. Pentru analiza citologică au fost evaluate mostre de calus fixate la 96 şi 192 ore de cultivare de la începutul iniţierii calusogenezei. În rezultatul examinării - 4133 celule calusale a fost stabilită cota celulelor cu aberaţii, care reprezintă procentul celulelor cu aberaţii raportat la numărul total de celule studiate în anatelofaza diviziunii mitotice.

Studiul influenţei radiaţiei gama asupra procesului de diviziune a celulelor din calus a demonstrat reacţii diferite ale genotipurilor cercetate. Devieri semnificative s-au observat la genotipurile: LT 76872, Colina și 188 TR 5027, numărul celulelor mitotice cu aberaţii constituind 28,20, 25,23 și respectiv 23,33\%. Cel mai mare număr de celule mitotice aberante a fost semnalat la genotipul LT 76872.

Numărul celulelor cu aberaţii cromozomiale în celulele calusale la genotipul Rodlen a constitui $15,50 \%$, pe când la varianta martor acest indice este doar de $4,56 \%$, ceea ce demonstrează aportul culturii in vitro și specificul genotipului în inducerea mutaţiilor. La genotipul Ingen 35 acest indice atinge valoarea de $13,61 \%$ în comparaţie cu martorul pentru care nu au fost depistate aberaţii.

S-a stabilit că efectul citogenetic al culturii in vitro este dependent prioritar de genotip, cât și de iradierea materialului cu raze gama, ce a favorizat creşterea cotei de celule cu aberaţii şi inducerea mutaţiilor cromozomiale. Datele obţinute ne demonstrează că, la doza de 150 Gy în comparaţie cu martorul, activitatea mitotică scade. Datorită acestei acţiuni, cromozomii suferă diverse restructurări. S-au observat aberaţii în anafază-telofază de tipul: punţi cromozomiale simple sau duble, cromozomi retardaţi, fragmente cromozomiale. Cel mai mare număr de aberaţii cromozomiale în procesul diviziunii mitotice îl constituie punţile cromozomiale şi fragmentele cromatidice. Anume aceste tipuri de aberaţii au o pondere mai importantă asupra procesului mutaţional, procese care determină spectrul variabilităţii genetice somaclonale. Astfel de schimbări structurale nu revin la starea normală şi deci, probabil sunt responsabile de apariţia unor forme mutante. Iradierea cu raze gama are efect puternic asupra procesului mitotic, prin reducerea indicelui mitotic şi prin provocarea de aberaţii cromozomiale. 